\title{
Photo-Induced Decomposition of 2-Chloroaniline in Aqueous Solution
}

\author{
Ermin Katrin Winarno ${ }^{\mathrm{a}}$ and Nikola Getoff $\mathrm{b}^{\mathrm{b}, *}$
}

a Centre for the Research and Development of Isotopes and Radiation Technology, National Nuclear Energy Agency, Jakarta, Indonesia

b Ludwig Boltzman Institute for Radiation Chemistry and Radiation Biology at the University of Vienna, A-1090 Wien, Althanstr. 14, Austria

* Author for correspondence and reprint requests

Z. Naturforsch. 57 c, 512-515 (2002); received August 29/December 28, 2001

Photodecomposition, 2-Chloroaniline, Effect of Oxygen and $\mathrm{N}_{2} \mathrm{O}$

A study was performed on the oxidizing degradation of 2-chloroaniline (used as a model pollutant in water) by photolysis $(\lambda=254 \mathrm{~nm})$. The change of spectrum and substrate concentration of treated solutions was measured spectrophotometrically as well as by HPLC. The yields of the degradation products (chloride ions, ammonium ions, formaldehyde, etc.) were studied as a function of UV-dose. Their initial quantum yields $\left(\mathrm{Q}_{\mathrm{i}}\right)$ were determined by specific analysis. It was shown that the substrate photolysis in the presence of $\mathrm{N}_{2} \mathrm{O}$ is most efficient, followed by degradation in media saturated with pure oxygen and air. A probable reaction mechanism for the photo-induced degradation of 2-ClA is presented.

\section{Introduction}

The rapid industrial development at the last decades is necessary to be balanced with the suitable and efficient methods for waste water treatment. The production and usage of various chlorine-containing pesticides and other chemicals, as well as fertilizer in modern agriculture, strongly contribute to contamination of ground water (Getoff, 1993; 1999).

Presently, various water treatment techniques have been developed, but the combination of ionizing radiation technique with ozone and/or catalysts as well as with $\mathrm{N}_{2} \mathrm{O}$, air, and oxygen seems to be the most promising method for the degradation of biologically resistant compounds (Cooper et al., 1998; Getoff, 1996; Woods and Pikaev, 1994). In recent years, the use of advanced oxidation processes involving the combination of UV-irradiation and oxidants $\left(\mathrm{O}_{3}, \mathrm{H}_{2} \mathrm{O}_{2}\right)$ and/or catalysts $\left(\mathrm{Fe}^{2+}, \mathrm{TiO}_{2}\right)$ has become an alternative to electron beam processing technology as well as to conventional water treatment plants e.g. (Alfassi, 1997; Krapfenbauer and Getoff, 1999).

The present paper deals with photolysis degradation of 2-chloroaniline in aqueous solution under various conditions in the presence of $\mathrm{N}_{2} \mathrm{O}$, air, or oxygen. Chlorinated anilines are used as starting substances for chemical synthesis and therefore can appear as pollutants in industrial waste water. Since up to now very little is known on photo-induced degradation of this group of substances, 2-chloroaniline was chosen as a model substrate for this study.

\section{Experimental}

Ortho-chloroaniline (2-ClA) was applied as a model compound in this work (Fluka AG, Buchs $\mathrm{SG}, \mathrm{d}_{4}^{20}=1.210$ ) and was used as received. All other chemicals were of p.a. quality. The solutions of $100 \mathrm{ml} 10^{-4} \mathrm{~mol} / \mathrm{l}$ 2-ClA were freshly prepared using 3-times distilled water and irradiated under various conditions.

To study the specific $\mathrm{OH}$-attack on 2-ClA, the solvated electrons $\left(\mathrm{e}_{\mathrm{aq}}^{-}\right)$are converted into $\mathrm{OH}$ radicals by saturation the aqueous solution with $2.8 \times 10^{-2}$ $\mathrm{mol} / \mathrm{l} \mathrm{N}_{2} \mathrm{O}$ gas of high purity at room temperature. Other series of experiments were saturated with air $\left(0.25 \times 10^{-3} \mathrm{~mol} / \mathrm{l} \mathrm{O}_{2}\right)$ as well as with high purity oxygen $\left(1.25 \times 10^{-3} \mathrm{~mol} / \mathrm{l} \mathrm{O}_{2}\right)$. In such case the "solvated electrons" $\left(\mathrm{e}_{\mathrm{aq}}^{-}\right)$, which can be photo-ejected from the $\mathrm{NH}_{2}$-group of the substrate (Getoff, 1989) and the $\mathrm{H}$-atoms, which might be also formed in the process of substrate photolysis, will be transformed into peroxyl radicals (see Eqns. 1-4).

A low pressure Hg-lamp (Osram HNS 12) with incorporated Vyctor filter provided monochromatic UV-light with $\lambda=254 \mathrm{~nm}$. By using aqueous $10^{-1}$ to $10^{-2} \mathrm{~mol} / 1 \mathrm{monochloroacetic} \mathrm{acid} \mathrm{as} \mathrm{actinometer}$ at $31 \pm 0.5^{\circ} \mathrm{C}$ and based on a quantum yield, 


$$
\begin{array}{lll}
\mathrm{N}_{2} \mathrm{O}+\mathrm{e}_{\mathrm{aq}}^{-} \longrightarrow \mathrm{OH}+\mathrm{OH}^{-}+\mathrm{N}_{2} & \left(k_{1}=0.91 \times 10^{10} \mathrm{M}^{-1} \mathrm{~s}^{-1}\right) \\
\mathrm{O}_{2}+\mathrm{H} & \longrightarrow \mathrm{HO}_{2} & \left(k_{2}=2.0 \times 10^{10} \mathrm{M}^{-1} \mathrm{~s}^{-1}\right) \\
\mathrm{O}_{2}+\mathrm{e}_{\mathrm{aq}}^{-} & \longrightarrow \mathrm{O}_{2}^{--} & \left(k_{3}=1.9 \times 10^{10} \mathrm{M}^{-1} \mathrm{~s}^{-1}\right) \\
\mathrm{HO}_{2} & \rightleftarrows \mathrm{H}^{+}+\mathrm{O}_{2}^{\circ-} & (\mathrm{pK}=4.8)
\end{array}
$$

$\mathrm{Q}\left(\mathrm{Cl}^{-}\right)=0.36 \pm 0.05$ (Neumann-Spallart and Getoff, 1975) the UV-intensity was determined. The mean value of several measurements was $I_{\mathrm{o}}=6.4 \times$ $10^{19} \mathrm{hv} \cdot 1^{-1} \cdot \min ^{-1}$. The irradiation apparatus for $4 \pi$ geometry used in all experiments was previously reported (Getoff and Schenck, 1968).

\section{Analysis}

The pollutant degradation was followed by measuring the absorption spectra after interval each absorbed UV-dose (spectrophotometer: Perkin Elmer, type LAMBDA 16, UV/VIS). Strong changes of the spectra (depending on the $\mathrm{pH}$ of the solution) were observed at the maxima: $231 \mathrm{~nm}$ and $285 \mathrm{~nm}$. The change of the optical density $(\mathrm{OD})$ at these wavelengths as a function of the absorbed dose were studied as indicator for the radiation-induced degradation of 2-ClA.

The photolysis of the substrate and the formation of various products were determined by HPLC-method (Hewlett-Packard, type 1046/1050 with computer online) using: column $150 \times 4.6 \mathrm{~mm}$ Cromasil 100-C18, solvent mixture: $\mathrm{MeOH}: \mathrm{H}_{2} \mathrm{O}=$ 5:1; flow rate: $1.0 \mathrm{ml} / \mathrm{min}$, electrochemical detector; or UV-VIS SPD 6A Shimadzu $(\lambda=210 \mathrm{~nm})$ detector; Shodex RS-pak KC-G column $(300 \times$ $8 \mathrm{~mm})$; eluent $0.03 \% \mathrm{H}_{3} \mathrm{PO}_{4}$ with flow rate: $1.0 \mathrm{ml} / \mathrm{min}$

Ammonia (measured as $\mathrm{NH}_{4}^{+}$) appeared as one of the degradation products. Its yield was determined by Nessler's reagent measuring the absorption at $410 \mathrm{~nm}$ (Charlot, 1964).

The method by Nash was applied and the formation of formaldehyde was followed by measuring the absorption maximum at $412 \mathrm{~nm}$ (Nash, 1953).

The formation of chloride ions as one of the radiolytic products was performed according to Florence and Farror (1971). The OD-values were registered at $460 \mathrm{~nm}$. In all cases calibration curves were established showing the concentration of the photolytic product as a function of the measured OD-values.

\section{Results and Discussion}

The solutions of $10^{-4} \mathrm{~mol} / \mathrm{l}$ 2-chloroaniline (2$\mathrm{ClA})$ were first saturated with $\mathrm{N}_{2} \mathrm{O}\left(2.8 \times 10^{-2}\right.$ $\mathrm{mol} / \mathrm{l})$, air $\left(2.5 \times 10^{-4} \mathrm{~mol} / 1 \mathrm{O}_{2}\right)$ or pure oxygen $\left(1.25 \times 10^{-3} \mathrm{~mol} / \mathrm{l} \mathrm{O}_{2}\right)$, respectively and the photoinduced substrate degradation was followed as function of the irradiation time. The obtained results are presented in Fig. 1. The initial quantum yields $\left(\mathrm{Q}_{\mathrm{i}}\right)$ of the degraded 2-ClA were calculated from the linear part of the individual curves and are given in the insert of Fig. 1.

Obviously, the highest degradation effect was obtained in the presence of $\mathrm{N}_{2} \mathrm{O}$ (curve A), followed by the experiments performed in pure oxygen (curve $\mathrm{C}$ ) and in the presence of air (curve B). Concurrently a $\mathrm{pH}$-decrease of all irradiated solutions was observed, indicating the formation of carboxylic acids and $\mathrm{Cl}^{-}$ions as degradation products. The initial quantum yields of the carboxylic acid mixture is presented as $\mathrm{Q}_{\mathrm{i}}\left(\mathrm{H}_{\mathrm{aq}}^{+}\right)$in Table I for each series of experiments. Obviously, in solution saturated with pure oxygen or $\mathrm{N}_{2} \mathrm{O}$ the substrate is degradated more efficiently leading to somewhat higher yields of carboxylic acids.

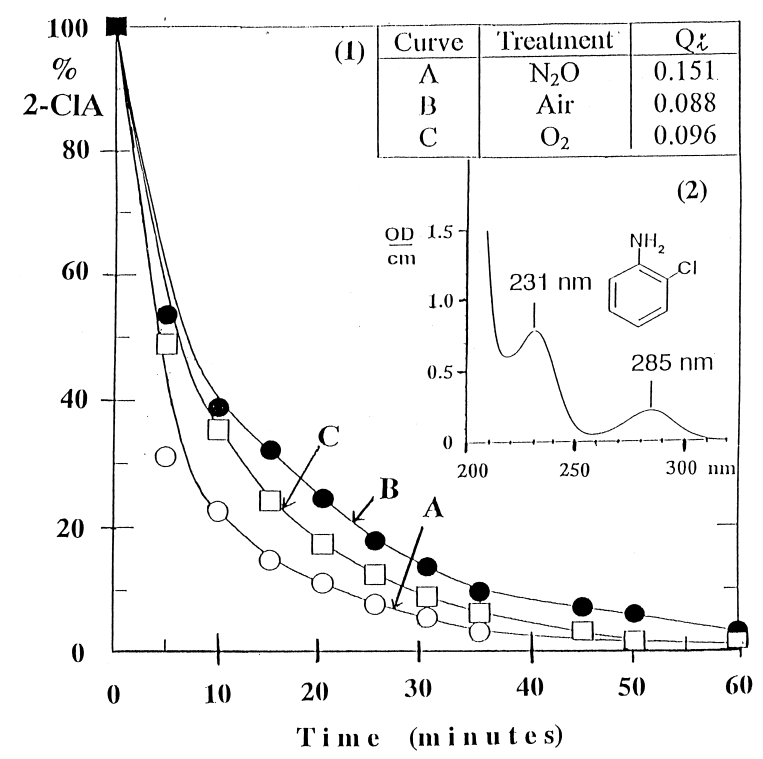

Fig. 1. Photo-induced degradation of $10^{-4}$ м 2-chloroaniline as a function of UV-light irradiation time at $\mathrm{pH} 6.8$ in the presence of $(A): \mathrm{N}_{2} \mathrm{O},(\mathrm{B})$ : air, and $(\mathrm{C})$ : pure $\mathrm{O}_{2}$. Inserts: (1) Initial quantum yields $\left(\mathrm{Q}_{\mathrm{i}}\right) ;(2)$ absorption spectrum of 2-ClA. 
Table I. Initial quantum yields $(\mathrm{Q} i)$ of photo-induced formation of formaldehyde and a mixture of carboxylic acids (expressed as $\mathrm{H}_{\mathrm{aq}}^{+}$ions) resulting from aqueous $10^{-4} \mathrm{~mol} / \mathrm{l}$ 2-chloroaniline $(\mathrm{pH}=6.8)$ in the presence of: (A) $2.8 \times 10^{-2} \mathrm{~mol} / 1 \mathrm{~N}_{2} \mathrm{O}$; (B) $2.5 \times 10^{-4} \mathrm{~mol} / 1 \mathrm{O}_{2}$; (C) $1.25 \times 10^{-3} \mathrm{~mol} / 1 \mathrm{O}_{2}$.

\begin{tabular}{llcc}
\hline Series & $\begin{array}{c}\text { Saturated } \\
\text { with }\end{array}$ & \multicolumn{2}{c}{$\mathrm{Q}_{\mathrm{i}}$-yields } \\
& $\mathrm{HCHO}_{2} \mathrm{O}$ & 0.0011 & $\mathrm{H}_{\mathrm{aq}}^{+}$ \\
\hline $\mathrm{A}$ & $\mathrm{Air}$ & 0.0013 & 0.020 \\
$\mathrm{~B}$ & $\mathrm{O}_{2}$ & 0.0006 & 0.010 \\
$\mathrm{C}$ & & 0.024 \\
\hline
\end{tabular}

The formation of $\mathrm{Cl}^{-}$ions as photolytic product of 2-ClA degradation under the given experimental conditions is presented as a function of the UV-light irradiation time in Fig. 2. The highest $\mathrm{Q}_{\mathrm{i}}\left(\mathrm{Cl}^{-}\right)$-value was observed in solutions saturated with $\mathrm{N}_{2} \mathrm{O}$ (see insert in Fig. 2).

This finding suggests that the yield of the photoejected $\mathrm{e}_{\mathrm{aq}}^{-}$from 2-ClA should be relatively high. It should be mentioned that under comparable conditions $\mathrm{Q}_{\mathrm{i}}\left(\mathrm{e}_{\mathrm{aq}}^{-}\right)=0.27$ for aniline has been previously reported (Getoff, 1989).

A further essential degradation product from 2-ClA was ammonia. Its formation in different media is presented in Fig. 3 in dependence of the irradiation time. Obviously, the highest $\mathrm{Q}_{\mathrm{i}}$-value resulted in solutions saturated with $\mathrm{N}_{2} \mathrm{O}$, but after a 10 -min irradiation time it decreases gradually. On the other hand the oxygen-containing solutions led to a much higher total yield of ammonia. In these

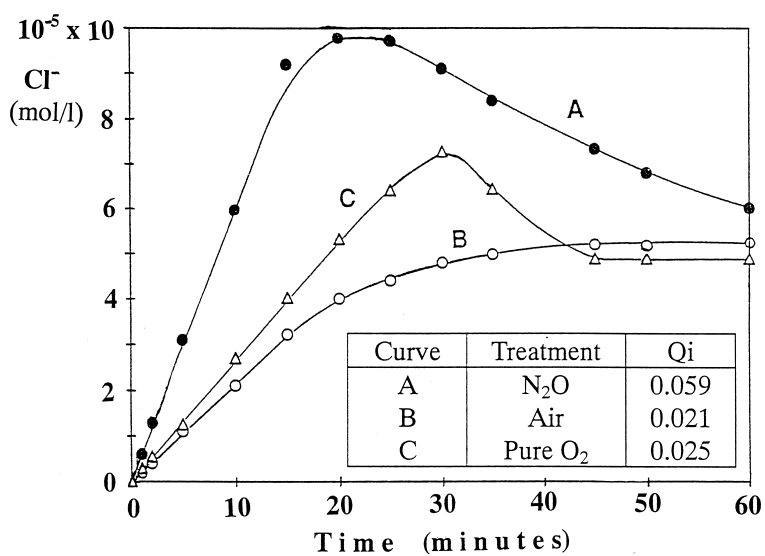

Fig. 2 : Photo-induced chloride ion formation from $10^{-4}$ м 2-chloroaniline as a function of UV-light irradiation time at $\mathrm{pH} 6.8$ in the presence of $(\mathrm{A}): \mathrm{N}_{2} \mathrm{O},(\mathrm{B})$ : air, and $(C)$ : pure $\mathrm{O}_{2}$. Inserts: Initial quantum yields $\left(\mathrm{Q}_{\mathrm{i}}\right)$. two cases the yield-dose curves were passing likewise a maximum, which indicates the involvement of ammonia in further reactions. The $\mathrm{Q}_{\mathrm{i}}$-data are shown in the insert of Fig. 3.

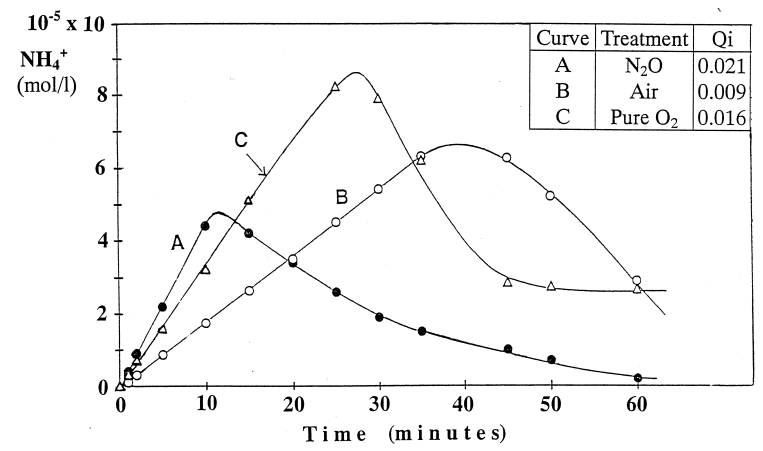

Fig. 3 : Photo-induced $\mathrm{NH}_{3} / \mathrm{NH}_{4}^{+}$formation from $10^{-4} \mathrm{M}$ 2-chloroaniline as a function of UV-light irradiation time at $\mathrm{pH} 6.8$ in the presence of (A): $\mathrm{N}_{2} \mathrm{O},(\mathrm{B})$ : air and (C): pure $\mathrm{O}_{2}$. Inserts : Initial quantum yields $\left(\mathrm{Q}_{\mathrm{i}}\right)$.

In addition to the above mentioned products also the formation of formaldehyde was of interest. The initial quantum yields of $\mathrm{HCHO}$ produced in the three media $\left(\mathrm{N}_{2} \mathrm{O}\right.$, air and pure oxygen) as a function of the absorbed UV-dose are presented also in Table I. In all three cases the $\mathrm{Q}_{\mathrm{i}}(\mathrm{HCHO})$-values are very low. Very likely the aldehyde is consumed by reactions with $\mathrm{OH}$ or/and $\mathrm{O}_{2}^{--}$species and is transformed to other products (Jung et al., 1994; Getoff, 1997).

$$
\begin{aligned}
& \mathrm{HCHO}+\mathrm{OH} \longrightarrow \mathrm{HC} \mathrm{O}+\mathrm{H}_{2} \mathrm{O} \quad\left(k=1 \times 10^{9} \mathrm{M}^{-1} \mathrm{~s}^{-1}\right. \text {; Hart et al., 1964) } \\
& \mathrm{HCHO}+\mathrm{O}_{2}^{--} \longrightarrow \mathrm{HC} \mathrm{O}+\mathrm{HO}_{2}^{-} \\
& \mathrm{HO}_{2}^{-}+\mathrm{H}^{+} \longrightarrow \mathrm{H}_{2} \mathrm{O}_{2} \\
& 2 \mathrm{HC} \mathrm{O} \\
& \quad \mathrm{HCHO}+\mathrm{CO} \\
& \longrightarrow(\mathrm{CHO})_{2} \text { (Glyoxal) }
\end{aligned}
$$

The species: $\mathrm{HCO}, \mathrm{HCHO}$ and $(\mathrm{CHO})_{2}$ in reality are present in hydrated form, e.g. $\mathrm{HCO} \equiv \mathrm{CH}(\mathrm{OH})_{2}$ etc.

In the presence of oxygen also oxalic acid can be formed:

$$
\begin{aligned}
& \mathrm{HC} \mathrm{O}+\mathrm{O}_{2} \longrightarrow \text { HCO-O }{ }_{2} \text { (Peroxyl radical) } \\
& 2 \mathrm{HCO}-\mathrm{O}_{2}^{\circ} \longrightarrow \mathrm{O}_{2}+(\mathrm{COOH})_{2} \quad(\text { Oxalic acid })
\end{aligned}
$$

Based on the results obtained by the photolysis $(\lambda=254 \mathrm{~nm})$ of aqueous $2-\mathrm{ClA}$ in the presence of various gases a probable reaction mechanism can be 
postulated. As a result of UV-light absorption the substrate molecules become electronically excited and can subsequently undergo various primary processes, e.g.:

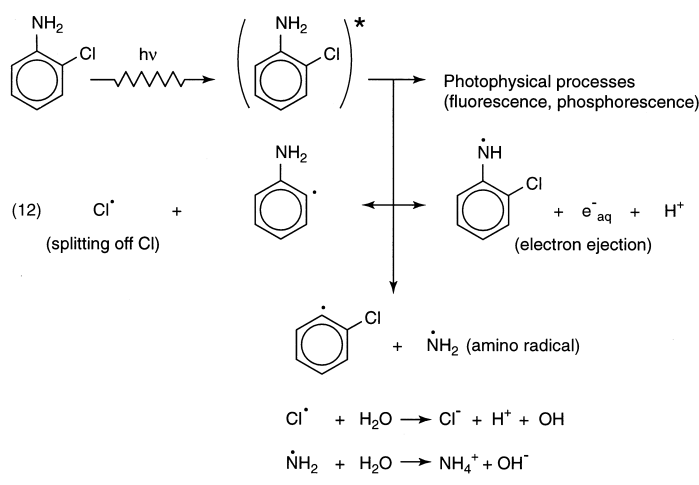

The $\mathrm{HO}_{2}^{-} / \mathrm{O}_{2}^{-}$and $\mathrm{OH}$ transients as well as $\mathrm{e}_{\mathrm{aq}}^{-}$ and $\mathrm{H}$ (see Eqns 1-4 and 11-14) can attack 2$\mathrm{ClA}$, e.g.:<smiles></smiles>

Alfassi Z. B. (ed.) (1997), The Chemistry of Free Radicals. Peroxyl Radicals. John Wiley \& Sons, Chichester, New York.

Charlot G. (1964), Colorimetric Determination of Elements - Principles and Methods. Elsevier Publ., Amsterdam, 320-321.

Cooper W. J., Curry R. D. and O'Shea K. E. (eds.) (1998), Environmental Applications of Ionizing Radiation. John Wiley \& Sons, New York.

Florence T. M. and Farror Y. T. (1971), Spectrophotometric determination of chloride in the parts-per-billion level by the mercury-II-thiocyanate method. Analyt. Chem. Acta 54, 373-377.

Getoff N. (1989), A review of the relationship between $\mathrm{Q}_{\mathrm{i}}\left(\mathrm{e}_{\mathrm{aq}}^{-}\right)$and $\mathrm{Q}_{\mathrm{F}}$ of excited compounds in aqueous solution. Radiat. Phys. Chem. 34, 711-719.

Getoff N. (1993), Purification of drinking water by irradiation. A review. Proc. Indian Acad. Sci. (Chem. Sci.) 105, 373-391.

Getoff N. (1996), Radiation-induced degradation of water pollutants - state of the art. Radiat. Phys. Chem. 47, $581-593$.

Getoff N. (1997), $\mathrm{CO}_{2}$ utilization using ionizing radiation and UV-light. A review. World Resource Rev. 9, 86100 .

The formation of $\mathrm{OH}$-adducts can result by $\mathrm{OH}$-attacks at $o-, m-, p$ - and ipso-positions (at the $\mathrm{C}$-atom bound to $-\mathrm{NH}_{2}$ or $-\mathrm{Cl}$ ). Each type of these $\mathrm{OH}-$ adducts can give rise to the formation of various end products.

It should be mentioned that in addition to the above-mentioned final products also several aromatic compounds, such as phenol, chlorophenol, aniline and a mixture of simple carboxylic acids have been found by HPLC-analysis. Their yield was rather low $\left(\mathrm{Q}<5 \times 10^{-7} \mathrm{~mol} / \mathrm{l}\right.$ and therefore not further studied.

\section{Acknowledgements}

One of us (Ermin Katrin Winarno) like to express her appreciation to the International Atomic Energy Agency for providing a fellowship, which made possible to perform this work. Thanks are also expressed to Mr. Horst Wolfgner and Dr. K. Krapfenbauer for their help and introduction to various analytical methods.

Getoff N. (1999), Radiation chemistry and environment. Radiat. Phys. Chem. 54, 377-384.

Getoff N. and Schenck G. O. (1968), Primary products of liquid water photolysis at $1236 \AA, 1470 \AA$ and $1849 \AA$. Photochem. Photobiol. 8, 167-178.

Hart E. J., Thomas J. K. and Gordon S. (1964), A review of the radiation chemistry of simple-carbon compounds and some reactions of the hydrated electron in aqueous solution. Radiat. Res., Suppl. 4, 74-88.

Jung H.-J., Getoff N. and Lorbeer E. (1994), Radiationinduced incorporation of $\mathrm{CO}$ in pure and aqueous methanol. Z. Naturforsch. 49a, 617-622.

Krapfenbauer K. and Getoff N. (1999), Comparative studies of photo- and radiation-induced degradation of aqueous EDTA. Synergistic effects of oxygen, ozone and $\mathrm{TiO}_{2}$. Radiat. Phys. Chem. 55, 385-393.

Nash T. (1953), The colorimetric estimation of formaldehyde. Biochemistry 55, 416-421.

Neumann-Spallart M. and Getoff N. (1975), Photolysis of monochlor acetic acid at $253.7 \mathrm{~nm}$ in aqueous solution (in German). Monatsh. Chem. 106, 1359-1367.

Woods R. J. and Pikaev A. K. (1994), Applied Radiation Chemistry: Radiation Processing. John Wiley \& Sons, New York. 